\title{
Electrolyte abnormalities in cystic fibrosis: systematic review of the literature
}

\author{
Elisabetta Scurati-Manzoni • Emilio F. Fossali • Carlo Agostoni • \\ Enrica Riva • Giacomo D. Simonetti • Maura Zanolari-Calderari • \\ Mario G. Bianchetti • Sebastiano A. G. Lava
}

Received: 18 August 2013 /Revised: 12 November 2013 / Accepted: 18 November 2013 / Published online: 11 December 2013

(C) IPNA 2013

\begin{abstract}
Background Cystic fibrosis per se can sometimes lead to hyponatremia, hypokalemia, hypochloremia or hyperbicarbonatemia. This tendency was first documented 60 years ago and has subsequently been confirmed in single case reports or small case series, most of which were retrospective. However, this issue has not been addressed analytically. We have therefore systematically reviewed and analyzed the available literature on this subject.

Methods This was a systematic review of the literature.

Results The reports included in this review cover 172 subacute and 90 chronic cases of electrolyte imbalances in patients with cystic fibrosis. The male:female ratio was 1.57. Electrolyte abnormalities were mostly associated with clinically inapparent fluid volume depletion, mainly affected
\end{abstract}

E. Scurati-Manzoni $\cdot$ E. F. Fossali

Pediatric Emergency Unit, De Marchi Hospital, Foundation IRCCS

Ca' Granda Ospedale Maggiore Policlinico, Milan, Italy

E. Scurati-Manzoni - M. Zanolari-Calderari • M. G. Bianchetti •

S. A. G. Lava

Integrated Department of Pediatrics, Ente Ospedaliero Cantonale

Ticinese, University of Berne, Bern, Switzerland

C. Agostoni

Second Pediatric Clinic, Clinica De Marchi, Foundation IRCCS Ca' Granda Ospedale Maggiore Policlinico, Department of Clinical

Sciences and Community Health, University of Milan, Milan, Italy

E. Riva

Department of Pediatrics, San Paolo Hospital, University of Milan, Milan, Italy

G. D. Simonetti $\cdot$ S. A. G. Lava

Pediatric Nephrology, University Children's Hospital Berne,

University of Berne, Bern, Switzerland

M. G. Bianchetti $(\square)$

San Giovanni Hospital, 6500 Bellinzona, Switzerland

e-mail: mario.bianchetti@pediatrician.ch patients aged $\leq 2.5$ years, frequently tended to recur and often were found before the diagnosis of cystic fibrosis was established. Subacute presentation often included an history of heat exposure, vomiting, excessive sweating and pulmonary infection. History of chronic presentation, in contrast, was often inconspicuous. The tendency to hypochloremia, hypokalemia and metabolic alkalosis was similar between subacute and chronic patients, with hyponatremia being more pronounced $(P<0.02)$ in subacute compared to chronic presentations. Subacute cases were treated parenterally; chronic ones were usually managed with oral salt supplementation. Retention of urea and creatinine was documented in $38 \%$ of subacute cases.

Conclusions The findings of our review suggest that physicians should be aware that electrolyte abnormalities can occur both as a presenting and a recurring feature of cystic fibrosis.

Keywords Cystic fibrosis $\cdot$ Hypokalemia $\cdot$ Hyponatremia Metabolic alkalosis

\section{Introduction}

Hyponatremia, hypokalemia, hypochloremia or hyperbicarbonatemia are conditions that can be found in cystic fibrosis patients on drug treatment $[1,2]$. Hyponatremia and hypokalemia can also be found in cystic fibrosis patients with diabetes mellitus, a major comorbidity of this disease. However, these electrolyte abnormalities are sometimes a consequence of the disease itself [3]. This tendency, first documented following heat exposure approximately 60 years ago [4], has subsequently been confirmed in several single case reports or small case series, most of which were retrospective. However, the subject has not been addressed analytically [3]. We therefore systematically reviewed and analyzed all available literature. Our aims were to describe in detail electrolyte abnormalities, suggest 
preventive and therapeutic tools and warn physicians about the possible occurrence of electrolyte abnormalities as a presenting feature and complication of cystic fibrosis.

\section{Methods}

Between October 2012 and August 2013 we conducted a thorough computer-based search for the terms "cystic fibrosis alkalosis," "cystic fibrosis electrolyte abnormalities," "cystic fibrosis Bartter's," "cystic fibrosis dehydration," "cystic fibrosis heat exhaustion," "cystic fibrosis hypoelectrolytemia," "cystic fibrosis hypokalemia,", "cystic fibrosis hyponatremia," "cystic fibrosis inappropriate antidiuretic hormone," "cystic fibrosis pseudo-Bartter's," "cystic fibrosis salt depletion" and "cystic fibrosis SIADH" in the U.S. National Library of Medicine database and in the Web-based Google research engine. For this purpose we used the principles established by the UK Economic and Social Research Council guidance on the conduct of narrative synthesis and on the Preferred Reporting Items for Systematic Reviews and Meta-Analyses statement [5]. For the final analysis we exclusively selected reports available as a full-length article or as a letter, all of which included individually described cases of hyponatremia $(\leq 134 \mathrm{mmol} / \mathrm{L})$, hypochloremia $(\leq 100 \mathrm{mmol} / \mathrm{L})$, hypokalemia $(\leq 3.4 \mathrm{mmol} / \mathrm{L})$ or alkalosis (bicarbonatemia $\geq 27 \mathrm{mmol} / \mathrm{L}$ ) in cystic fibrosis patients with or without a pathological increase in blood urea and creatinine values. Characteristic gastrointestinal or pulmonary findings and a persistently elevated sweat chloride concentration $(\geq 60 \mathrm{mmol} / \mathrm{L}$ ) were the prerequisites for diagnosis [3]. Studies addressing the mechanisms underlying the tendency towards the above-mentioned electrolyte abnormalities were also sought. Reports published in languages other than English, French, German, Italian, Portuguese or Spanish were excluded. If the same case was present in different publications, we considered the most complete description.

Reports of cystic fibrosis patients with electrolyte abnormalities possibly caused by drugs (especially thiazide or loop diuretics and alkalinizing agents such as calcium carbonate or sodium bicarbonate), by cystic fibrosis-related diabetes mellitus or by acute diarrhea were excluded. Patients with a medical history consistent with posthypercapnic alkalosis were also excluded [6]. The presentation was considered subacute when linked to circumstances such as hot weather, vomiting or a respiratory disease and lasted $\leq 14$ days $[7,8]$. On the contrary, the presentation was considered chronic in patients without symptoms or with symptoms that persisted $>14$ days $[7,8]$. The following data for each case were collected: age, gender, laboratory test results, heat exposure, clinical presentation, chest infection, tendency of the electrolyte abnormalities to recur and previous diagnosis of cystic fibrosis. The genotype was not specifically addressed since in cystic fibrosis the association between the physical trait and the underlying genotype is not strong [9].

Numerical data were presented either as the median and interquartile range or as a "box and whiskers plot", categorical data were presented as relative frequency. The two-sided Wilcoxon-Mann-Whitney test and the Fisher exact test were performed for analysis. Significance was assumed when $P$ was $<0.05$.

\section{Research results}

The flowchart of the literature research process (Fig. 1) indicates that the initial research resulted in the identification of 408 publications of which 228 remained after duplicates (i.e. publications found with two or more research terms) were excluded. Of these 228 publications, 168 were reviewed in detail and 70 were retained for the final analysis. Thirty-one reports relevant to the subject were found in the references of these latter 70 reports. Hence, a total of 101 reports published between 1951 and 2013 were included in the final analysis [4, 7, 8, 10-107]: 88 in English [4, 7, 8, 10-94], six in Spanish [95-100], three in German [101-103], two in French [104, $105]$ and two in Portuguese [106, 107]. They had been reported from the following countries: Arab Emirates $(N=1)$, Argentina $(N=1)$, Australia $(N=4)$, Austria $(N=1)$, Belgium $(N=2)$, Brazil $(N=2)$, Canada $(N=6)$, Chile $(N=3)$, China $(N=1)$, Cuba $(N=1), \operatorname{Egypt}(N=1)$, France $(N=5)$, Germany $(N=3)$, Great Britain $(N=9)$, Greece $(N=2)$, India $(N=1)$, Iran $(N=1)$, Italy $(N=3)$, Jordan $(N=1)$, Kuwait $(N=1)$, Lebanon $(N=1)$, Nepal $(N=1)$, Panama $(N=1)$, Puerto Rico $(N=1)$, Peru $(N=1)$, Saudi Arabia $(N=1)$, Serbia $(N=2)$, Spain $(N=5)$, Sweden $(N=1)$, Switzerland $(N=5)$, Thailand $(N=2)$, Turkey $(N=7)$, United States of America $(N=24)$.

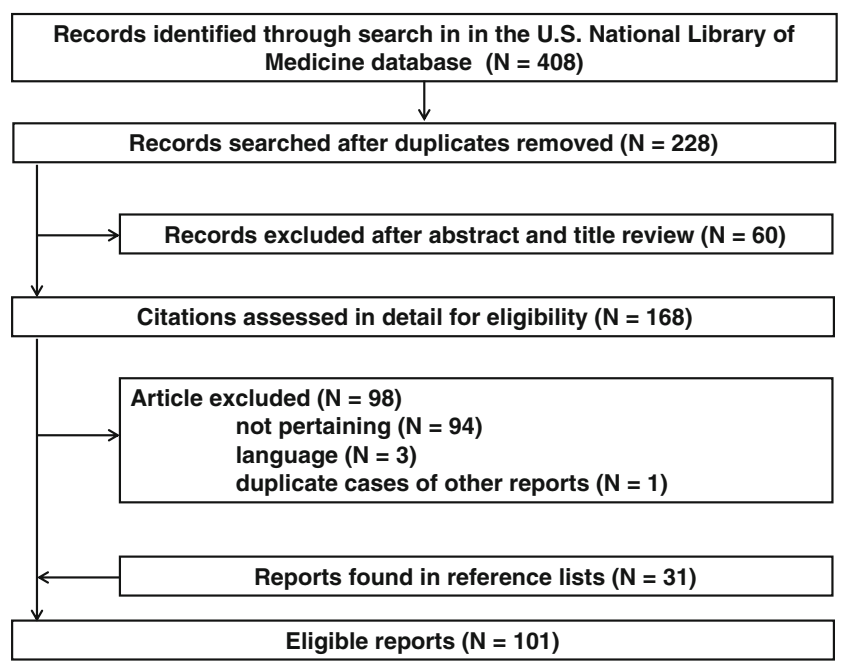

Fig. 1 Flowchart of the literature research process. Of the 101 reports included in the final analysis, 11 were identified exclusively from the Web-based Google research engine 


\section{Results}

Presentation

In the 262 cystic fibrosis patients (male:female ratio $1.57 ; P<$ 0.01 ) described in the 101 reports reviewed, hypochloremia (noted in 219/223 patients with this measurement), hyponatremia (in 206/218 patients), hyperbicarbonatemia (in $188 / 205$ patients) or hypokalemia (in 161/199 patients) were found. Most cases of these electrolyte imbalances were in combination with some other condition, but less frequently they occurred in isolation (an electrolyte abnormality was detected in isolation when the other electrolytes went unmeasured), as shown in Table 1 . Three-quarters of the patients were $\leq 2.5$ years of age when diagnosed with electrolyte abnormalities, and approximately $60 \%$ were diagnosed with electrolyte abnormalities before cystic fibrosis was identified (in at least 36 of these patients, a pediatric kidney disease specialist was involved because the initial diagnosis of Bartter syndrome was suspected). Circulating renin and aldosterone levels (Table 1), assessed only in a minority of cases, were almost always elevated (90\% and $86 \%$, respectively).

Clinical presentation was subacute in 172 cystic fibrosis patients $(66 \%)$ and chronic in the remaining 90 (34\%). Hyponatremia was significantly $(P<0.02)$ more pronounced in patients with subacute rather than with chronic presentation (Table 1; Fig. 2). Renal function studies were performed only in a minority of subacute cases $(N=69)$, with retention of urea and creatinine documented in 26 patients (38\%).
Blood Level (mmol/L) Sodium Chloride Potassium Bicarbonate

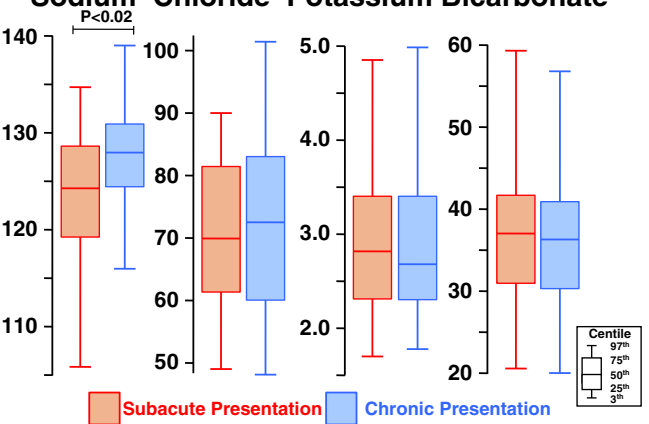

Fig. 2 Blood levels of sodium, chloride, potassium and bicarbonate in cystic fibrosis patients with electrolyte abnormalities. The results are given as "box and whiskers plot": bottom and top of box 25th and 75th centile, respectively, middle of box 50th centile (the median), ends of whiskers 3rd and 97th centile, respectively

In patients with either subacute or chronic presentation, these electrolyte abnormalities were associated with respiratory infections, excessive sweating, increased body temperature, failure to thrive, vomiting, heat exposure and fluid volume depletion, but they were significantly more frequent in patients with subacute presentation (Table 2). Tendency to recur was found in both subacute and chronic presentations, but was significantly $(P<0.02)$ more common in subacute cases. Respiratory disease was significantly more pronounced in patients with electrolyte abnormalities than in those without these abnormalities in both subacute and in chronic cases [70, 94]. All reported patients had normal or low blood

Table 1 Laboratory values in cystic fibrosis patients with a tendency to hyponatremia $(\leq 134 \mathrm{mmol} / \mathrm{L})$, hypokalemia $(\leq 3.4 \mathrm{mmol} / \mathrm{L})$, hypochloremia $(\leq 100 \mathrm{mmol} / \mathrm{L})$ or hyperbicarbonatemia $(\geq 27 \mathrm{mmol} / \mathrm{L})$

\begin{tabular}{|c|c|c|c|c|c|c|c|}
\hline \multirow[t]{2}{*}{ Demographic and clinical data } & \multicolumn{2}{|l|}{ All } & \multicolumn{2}{|c|}{ Subacute presentation } & \multicolumn{2}{|c|}{ Chronic presentation } & \multirow[t]{2}{*}{ Significance (subacute vs. chronic } \\
\hline & $N$ & Value & $N$ & Value & $N$ & Value & \\
\hline Gender, males/females $(N)$ & 262 & $160 / 102^{\mathrm{b}}$ & 172 & $109 / 63^{b}$ & 90 & $51 / 39^{\mathrm{b}}$ & NS \\
\hline Age (years) & 262 & $0.58[0.33-2.5]$ & 172 & $0.50[0.33-2.5]$ & 90 & $0.58[0.40-2.4]$ & NS \\
\hline Cystic fibrosis undiagnosed $(N)$ & 262 & 152 & 172 & 112 & 90 & 40 & $P<0.005$ \\
\hline Kidney injury $(N)$ & 69 & 26 & 69 & 26 & - & - & - \\
\hline \multicolumn{8}{|l|}{ Circulating } \\
\hline Sodium $(\mathrm{mmol} / \mathrm{L})$ & 218 & 125 [120-129] & 156 & 124 [119-129] & 62 & $127[122-131]$ & $P<0.02$ \\
\hline Potassium (mmol/L) & 199 & $2.8[2.3-3.4]$ & 138 & $2.8[2.4-3.4]$ & 61 & $2.6[2.1-3.2]$ & NS \\
\hline Chloride (mmol/L) & 223 & $71[62-81]$ & 146 & $71[63-82]$ & 77 & $70[60-81]$ & NS \\
\hline Bicarbonate $(\mathrm{mmol} / \mathrm{L})$ & 205 & $37[32-42]$ & 123 & 38 [33-42] & 82 & $36[31-41]$ & NS \\
\hline Renin ${ }^{\mathrm{a}}$, elevated & 31 & 28 & 18 & 16 & 13 & 12 & NS \\
\hline Aldosterone, elevated & 29 & 25 & 16 & 14 & 13 & 11 & NS \\
\hline
\end{tabular}

NS, Not significant

Numerical data are presented as the median and interquartile range (IQR) in square brackets; categorical data as are presented as relative frequency, unless otherwise indicated

${ }^{a}$ Estimated by either assays of plasma renin activity or by direct renin assay

${ }^{\mathrm{b}} P<0.01$ (male vs. female) 
pressure, except for an adolescent with a tendency to arterial hypertension [80]. Sodium, potassium and chloride urinary excretion were found to be reduced when measured before treatment for fluid and electrolyte repair was initiated.

An adolescent with cystic fibrosis who took part in a football practice on a summer morning developed rhabdomyolysis and was found to be dehydrated and hyponatremic [49].

Metabolic alkalosis may lead to compensatory hypoventilation and $\mathrm{CO}_{2}$ retention. To address this, an Australian group evaluated the acid-base balance in cystic fibrosis patients with chronic hypercapnia or exacerbations of respiratory disease and in adult patients with hypercapnia due to an exacerbation of their chronic obstructive pulmonary disease. The results of that study showed that metabolic alkalosis contributes to hypercapnic respiratory failure in cystic fibrosis patients during exacerbation of the disease itself [44].

Prevalence of electrolyte abnormalities at diagnosis of cystic fibrosis

Our literature research revealed only four reports addressing the prevalence of electrolyte abnormalities when cystic fibrosis was diagnosed. Hyponatremia was observed at diagnosis in 19 of 20 (95\%) Brazilian patients [42], whereas hypokalemia, hyponatremia and hyperbicarbonatemia were found in ten of 110 (9\%) Jordanian patients [94], four of 13 (31\%) Peruvian patients [95] and five of 120 (4\%) Indian patients [48].

Causes and clinical signs of fluid volume depletion in cystic fibrosis

A few of the identified studies investigated the mechanisms responsible for extracellular fluid volume depletion and electrolyte abnormalities in cystic fibrosis $[16,21,55,57,81]$. The results were as follows:

1) These patients underestimated their fluid needs and experienced excessive dehydration during extended exposure to hot climates and during intense physical activity $[16,55]$.
2) In cystic fibrosis, sweat production, occurring under conditions such as heat exposure or sport performances, was associated with an increase in sodium concentration in the sweat by approximately $30 \mathrm{mmol} / \mathrm{L}$ [21].

3) In salt-depleted patients with cystic fibrosis, clinical signs of extracellular fluid depletion, such as pallor, prolonged capillary refill, abnormal skin turgor, absent tears, dry mucous membranes, sunken eyes and tachycardia, were clinically less evident than in control subjects [57].

4) Apparently well hydrated and clinically stable cystic fibrosis patients had a low urinary sodium excretion [81] with elevated levels of both circulating renin and aldosterone [57], thus suggesting the presence of a chronic condition of fluid volume depletion.

Syndrome of inappropriate antidiuresis

Three patients with advanced cystic fibrosis ( 2 men and 1 woman, aged 23, 25 and 28 years, respectively) and a pulmonary exacerbation presented with hyponatremia (lowest value from 114 to $123 \mathrm{mmol} / \mathrm{L}$ ) and no clinical signs of extracellular fluid volume depletion. Their acid-base balance and potassium level were normal, blood urea level was rather low and sodium and chloride urinary excretion were rather high. Hence, the diagnosis of syndrome of inappropriate antidiuresis was entertained [25, 77, 84].

\section{Prevention and management of dyselectrolytemia}

The salt content of a normal diet and of both breast milk and infant formula may well be inadequate to meet general nutritional requirements of cystic fibrosis patients [24, 26]. It has therefore been recommended that infants with cystic fibrosis who are fed breast milk or milk formula should normally be provided a sodium chloride supplement of $3 \mathrm{mmol} / \mathrm{kg}$ body weight. This dosage should be increased to $5-6 \mathrm{mmol} / \mathrm{kg}$ of body weight under circumstances such as hot weather, arid climate, excessive house heating or sports activity [24, 26,
Table 2 Factors associated with hyponatremia, hypokalemia, hypochloremia or hyperbicarbonatemia in patients with cystic fibrosis

Data are presented as the number $(N)$ of patients

\begin{tabular}{lllll}
\hline $\begin{array}{l}\text { Factors associated } \\
\text { with electrolyte } \\
\text { imbalance }\end{array}$ & $\begin{array}{l}\text { All patients } \\
(N=262)\end{array}$ & $\begin{array}{l}\text { Patients with } \\
\text { subacute presentation } \\
(N=172)\end{array}$ & $\begin{array}{l}\text { Patients with } \\
\text { chronic presentation } \\
(N=90)\end{array}$ & $\begin{array}{l}\text { Significance } \\
\text { (subacute vs. } \\
\text { chronic) }\end{array}$ \\
\hline $\begin{array}{l}\text { Dehydration } \\
\text { Heat exposure }\end{array}$ & 146 & 133 & 13 & $P<0.0001$ \\
Vomiting & 127 & 105 & 22 & $P<0.0001$ \\
Failure to thrive & 94 & 79 & 15 & $P<0.0001$ \\
Increased body temperature & 75 & 48 & 40 & $P<0.002$ \\
Excessive sweating & 48 & 61 & 14 & $P<0.0001$ \\
Chest infection & 40 & 45 & 3 & $P<0.0001$ \\
Tendency to recur & 71 & 35 & 5 & $P<0.001$ \\
\hline
\end{tabular}


54]. Nonetheless, the authors of one study reported that an infant with cystic fibrosis developed severe hypernatremia $(177 \mathrm{mmol} / \mathrm{L})$ as a result of a misunderstood excessive daily supplement with one heaped teaspoon of table salt throughout a 3-week period [22].

Subacute dehydration and electrolyte abnormalities were repaired through the parenteral route in all reported cases, except for three rather mild cases that were managed by administration of oral rehydration solutions [17, 91, 93].

\section{Discussion}

This analysis shows that electrolyte abnormalities in cystic fibrosis patients are almost always associated with fluid volume depletion and are often clinically inapparent. Metabolic alkalosis and hypokalemia mainly result from renal tubular bicarbonate reabsorption, hydrogen secretion and potassium excretion, all of which are crucially regulated by a chloride-bicarbonate exchanger located on the intercalated cells and maintained in the presence of a reduced renal function [108]. This laboratory constellation is currently termed chloride depletion hypokalemic alkalosis instead of volume contraction hypokalemic alkalosis [108], taking into account that chloride depletion is the most significant factor responsible for these electrolyte abnormalities (Fig. 3).

These electrolyte abnormalities mainly affect cystic fibrosis patients aged $\leq 2.5$ years, involve males more frequently than females, tend to recur and are often recognized before cystic fibrosis is diagnosed. Patients with subacute presentation of electrolyte abnormalities and dehydration often have a recent history of heat exposure, vomiting, excessive sweating, increased body temperature and respiratory infection. By contrast, the medical history of patients with chronic presentation is inconspicuous and subtle.

Medical history, low sodium, potassium and chloride urinary excretion, frequent activation of the renin-aldosterone system and occasional occurrence of some transient kidney injury in patients with subacute presentation all support the association between electrolyte abnormalities and fluid volume depletion in cystic fibrosis patients [109]. These patients underestimate their fluid needs and experience dehydration during exposure to heat conditions and physical activity at a time when they have an enhanced sweat production. Furthermore, a persisting and subtle condition of fluid volume depletion is often present in clinically stable and apparently well-hydrated cystic fibrosis patients.

Our review of the literature revealed a few adults with advanced cystic fibrosis who experienced an isolated hyponatremia event without fluid volume depletion and who were diagnosed with a syndrome of inappropriate antidiuresis [109]. However, we did not identify any case of hyponatremia due to inappropriate antidiuresis in children, adolescents or adults without advanced lung disease.

There are four possible consequences of electrolyte abnormalities in cystic fibrosis. These are:

1) Persistent sodium chloride depletion may cause failure to thrive [110]: even though in this condition poor growth is mainly linked to both pancreatic and lung disease, we posit that failure to thrive might at times also be related to chronic electrolyte abnormalities.

2) The lung disease of cystic fibrosis primarily develops because thick mucus plugs predispose to respiratory infections [9]. With electrolyte abnormalities and fluid volume depletion present, it is tempting to speculate that in cystic fibrosis electrolyte abnormalities might further
Fig. 3 Mechanisms underlying the development of electrolyte abnormalities in cystic fibrosis. The crucial role of a reduced renal function is not addressed in the figure. $A D H$ Antidiuretic hormone

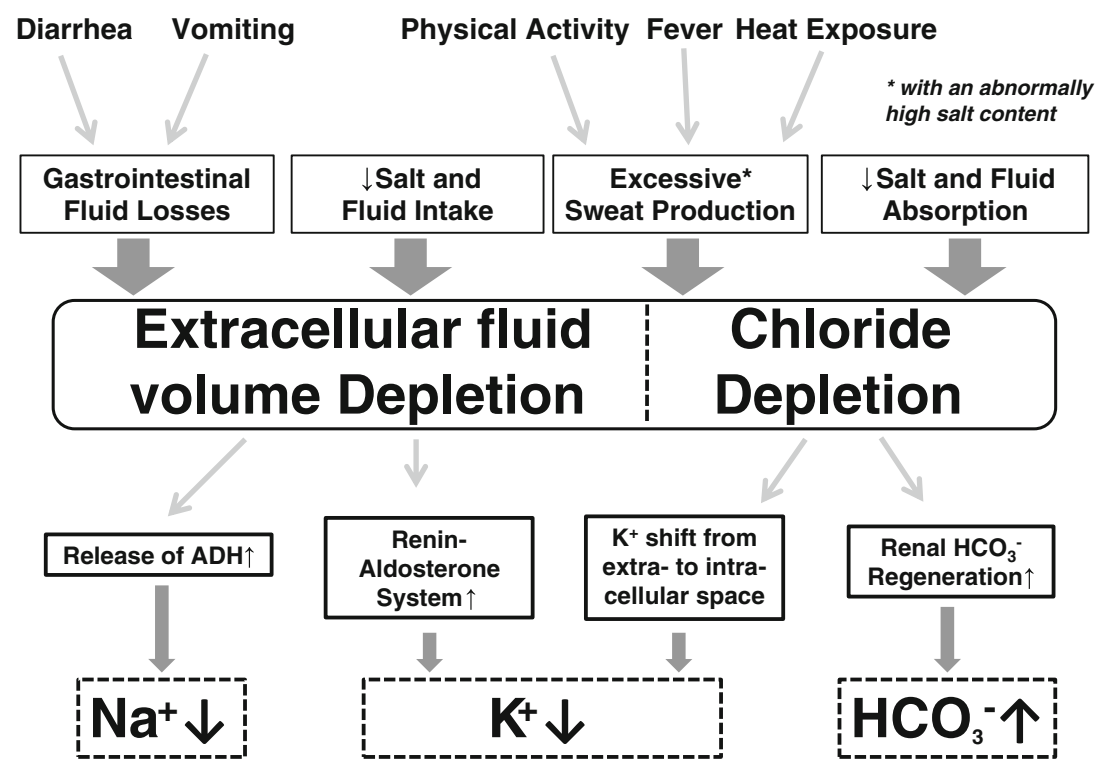


worsen the density and the viscosity of the mucus secretions.

3) In subjects with hyperbicarbonatemia, $\mathrm{CO}_{2}$ retention develops in order to restore blood hydrogen ion concentration towards normal. Hence, in some cystic fibrosis patients, $\mathrm{CO}_{2}$ retention might be linked not only to the lung disease but also to the hyperbicarbonatemia.

4) Adults with cystic fibrosis possess various potential risk factors for the development of chronic kidney disease, including cystic fibrosis-related diabetes mellitus, nephrotoxic drug exposure, secondary amyloidosis and absorptive hyperoxaluria. We speculate that in this hereditary disease recurrent but often clinically inapparent fluid volume depletion might be a further risk factor for chronic kidney disease.

In patients with subacute presentation, fluid volume depletion and electrolyte abnormalities require parenteral fluid and electrolyte replacement with solutions rich in sodium, potassium and chloride. Similar to the treatment for hypertrophic pyloric stenosis, many institutions give dehydrated cystic fibrosis patients with electrolyte abnormalities a $5 \%$ glucose solution that contains sodium chloride at approximately $80 \mathrm{mmol} / \mathrm{L}$ and potassium chloride at $15-25 \mathrm{mmol} / \mathrm{L}$ [111]. Unfortunately, assessment of the fluid volume state of these patients based on physical examination and history is inaccurate. Yet, in cases with metabolic alkalosis, the severity of alkalosis may help clinicians estimate the fluid volume status and, therefore, the amount of fluid required for repair: $10 \mathrm{ml} / \mathrm{kg}$ of body weight of the above-mentioned solution reduces circulating bicarbonate by approximately $3 \mathrm{mmol} / \mathrm{L}$ [111]. Rather severe hyponatremic $(<120 \mathrm{mmol} / \mathrm{L})$ parenteral repair consists of a normal saline solution [108]. Most patients with chronic presentation require daily oral salt supplementation with $3 \mathrm{mmol} / \mathrm{kg}$ body weight. This dosage should be increased to $5-6 \mathrm{mmol} / \mathrm{kg}$ under particular circumstances such as hot weather, arid climate, excessive house heating or sport activities. When cystic fibrosis patients present with a severe form of chronic electrolyte abnormalities and dehydration, a period of extra-enteral (or parenteral) fluid and salt supplementation could be necessary.

A significant limitation of this review is that the analysis almost exclusively incorporated information from single case reports or small retrospective case series of cystic fibrosis patients. No attempt was made to objectively measure the body water compartments of the patients. Finally, therapeutic and preventive recommendations do not arise from scientific analysis or clinical outcomes, but from authors' opinions.

\section{Conclusion}

Cystic fibrosis itself tends to electrolyte abnormalities, such as hypochloremia, hyponatremia, hypokalemia or hyperbicarbonatemia, that are almost always associated with an often clinically inapparent fluid volume depletion. In such cases, kidney disease specialists are sometimes involved because the diagnosis of Bartter syndrome is initially suspected by general pediatric practitioners (the fractional chloride excretion, which is $>1.510^{-2}$ in Bartter syndrome and $<0.510^{-2}$ in cystic fibrosis and other conditions with strong renal salt retention, is a crucial diagnostic clue). While subacute presentation is treated parenterally, chronic presentation is managed with daily oral salt supplementation.

Acknowledgments The authors are very grateful to Mrs. Mary Coduri for linguistic consultation.

Funding None.

Conflict of interest statement None.

\section{References}

1. Liamis G, Milionis H, Elisaf M (2008) A review of drug-induced hyponatremia. Am J Kidney Dis 52:144-153

2. Greenlee M, Wingo CS, McDonough AA, Youn JH, Kone BC (2009) Narrative review: evolving concepts in potassium homeostasis and hypokalemia. Ann Intern Med 150:619-625

3. Kerem E (2006) Atypical CF and CF related diseases. Paediatr Respir Rev 7[Suppl 1]:S144-S146

4. Kessler WR, Andersen DH (1951) Heat prostration in fibrocystic disease of the pancreas and other conditions. Pediatrics 8:648-656

5. Moher D, Liberati A, Tetzlaff J, Altman DG, PRISMA Group (2009) Preferred reporting items for systematic reviews and metaanalyses: the PRISMA statement. Ann Intern Med 151:264-269

6. Anonymous (1964) Convulsions after therapy for alveolar hypoventilation. JAMA 189:1023

7. Sojo A, Rodríguez-Soriano J, Vitoria JC, Vazquez C, Ariceta G, Villate A (1994) Chloride deficiency as a presentation or complication of cystic fibrosis. Eur J Pediatr 153:825-828

8. Beckerman RC, Taussig LM (1979) Hypoelectrolytemia and metabolic alkalosis in infants with cystic fibrosis. Pediatrics 63:580-583

9. O'Sullivan BP, Freedman SD (2009) Cystic fibrosis. Lancet 373: 1891-1904

10. Akgün C, Başaranoğlu M, Yuca SA, Akbayram S, Arslan Ş, Kirimi E (2009) Pseudo-Bartter's syndrome associated with cystic fibrosis. Nobel Med 5:43-45

11. Al-Ghimlas F, Faughnan ME, Tullis E (2012) Metabolic alkalosis in adults with stable cystic fibrosis. Open Respir Med J 6:59-62

12. Arvanitakis SN, Lobeck CC (1973) Metabolic alkalosis and salt depletion in cystic fibrosis. J Pediatr 82:535-545

13. Augusto JF, Sayegh J, Malinge MC, Illouz F, Subra JF, Ducluzeau PH (2008) Severe episodes of extra cellular dehydration: an atypical adult presentation of cystic fibrosis. Clin Nephrol 69:302-305

14. Baird JS, Walker P, Urban A, Berdella M (2002) Metabolic alkalosis and cystic fibrosis. Chest 122:755-756

15. Ballestero Y, Hernandez MI, Rojo P, Manzanares J, Nebreda V, Carbajosa H, Infante E, Baro M (2006) Hyponatremic dehydration as a presentation of cystic fibrosis. Pediatr Emerg Care 22:725-727

16. Bar-Or O, Blimkie CJ, Hay JA, MacDougall JD, Ward DS, Wilson WM (1992) Voluntary dehydration and heat intolerance in cystic fibrosis. Lancet 339:696-699 
17. Bates CM, Baum M, Quigley R (1997) Cystic fibrosis presenting with hypokalemia and metabolic alkalosis in a previously healthy adolescent. J Am Soc Nephrol 8:352-355

18. Beckerman RC (1979) Metabolic alkalosis in infants with cystic fibrosis. Pediatrics 64:389

19. Berezin S, Ruddy RM, Dozor AJ, Newman L (1989) Hypoelectrolytemia, hypovolemia, and alkalosis in cystic fibrosis with wood-burning stove in winter. Pediatr Emerg Care 5:189-190

20. Bianchetti MG, Mauri S (1996) Hypotonic dehydration in cystic fibrosis: mild or severe disease phenotype? J Pediatr 128:723

21. Bijman J (1987) Transport processes in the eccrine sweat gland. Kidney Int Suppl 21:S109-S112

22. Carlile JR, Pafford DM, Waring WW (1983) Severe hypernatremia in cystic fibrosis. Am J Dis Child 137:702-703

23. Chan LL, Osmond DH, Balfe JW, Halperin ML (1981) Plasma "prorenin"-renin in Bartter's syndrome, cystic fibrosis, and chloride deficiency, and the effect of prostaglandin synthetase inhibition. J Lab Clin Med 97:785-790

24. Coates AJ, Crofton PM, Marshall T (2009) Evaluation of salt supplementation in CF infants. J Cyst Fibros 8:382-385

25. Cohen LF, di Sant'Agnese PA, Taylor A, Gill JR Jr (1977) The syndrome of inappropriate antidiuretic hormone secretion as a cause of hyponatremia in cystic fibrosis. J Pediatr 90:574-578

26. Corbeel L, Proesmans W (1994) Dehydration associated with hypochloraemic alkalosis and cystic fibrosis. Eur J Pediatr 153:792

27. Davé S, Honney S, Raymond J, Flume PA (2005) An unusual presentation of cystic fibrosis in an adult. Am J Kidney Dis 45: e41-e44

28. Davison AG, Snodgrass GJ (1983) Cystic fibrosis mimicking Bartter's syndrome. Acta Paediatr Scand 72:781-783

29. Devlin J, Beckett NS, David TJ (1989) Elevated sweat potassium, hyperaldosteronism and pseudo-Bartter's syndrome: a spectrum of disorders associated with cystic fibrosis. J R Soc Med 82:38-43

30. Di Sant'Agnese PA, Darling RC, Perera GA, Shea E (1953) Abnormal electrolyte composition of sweat in cystic fibrosis of the pancreas. Pediatrics 12:549-563

31. Di Sant'Agnese PA (1960) Salt depletion in cold weather in infants with cystic fibrosis of the pancreas. JAMA 172:2014-2021

32. Eigenmann P, Délèze G, Kuchler H (1991) Chronic metabolic alkalosis in an infant with cystic fibrosis. Eur J Pediatr 150:669-670

33. English MC (1993) Clinical quiz. Pediatr Nephrol 7:119-120

34. Epaud R, Girodon E, Corvol H, Niel F, Guigonis V, Clement A, Feldmann D, Bensman A, Ulinski T (2005) Mild cystic fibrosis revealed by persistent hyponatremia during the French 2003 heat wave, associated with the S1455X C-terminus CFTR mutation. Clin Genet 68:552-553

35. Escobar Castro H, Medina E, Kirchschläger E, Camarero C, Suarez L (1995) Metabolic alkalosis with hypo-electrolytaemia or pseudoBartter syndrome as a presentation of cystic fibrosis in infancy. Description of three cases. Eur J Pediatr 154:868-869

36. Forsyth JS, Gillies DR, Wilson SG (1982) Cystic fibrosis presenting with chronic electrolyte depletion, metabolic alkalosis and hyperaldosteronism. Scott Med J 27:333-335

37. Fustik S, Pop-Jordanova N, Slaveska N, Koceva S, Efremov G (2002) Metabolic alkalosis with hypoelectrolytemia in infants with cystic fibrosis. Pediatr Int 44:289-292

38. Geara AS, Parikh A, Rekhtman Y, Rao MK (2012) The Case Metabolic alkalosis in a patient with cystic fibrosis. Kidney Int 81: $421-422$

39. Gökçe S, Süoğlu OD, Celtik C, Aydoğan A, Sökücü S (2007) Cystic fibrosis and hypoelectrolytemia. Pediatr Emerg Care 23:760

40. Gottlieb RP (1971) Metabolic alkalosis in cystic fibrosis. J Pediatr 79:930-936

41. Greig F, Schoeneman MJ, Kandall SR, Bonforte RJ (1993) Neonatal hyponatremic dehydration as an initial presentation of cystic fibrosis. Clin Pediatr (Phila) 32:548-551
42. Guimarães EV, Schettino GC, Camargos PA, Penna FJ (2012) Prevalence of hyponatremia at diagnosis and factors associated with the longitudinal variation in serum sodium levels in infants with cystic fibrosis. J Pediatr 161:285-289

43. Hochman HI, Feins NR, Rubin R, Gould J (1976) Chloride losing diarrhoea and metabolic alkalosis in an infant with cystic fibrosis. Arch Dis Child 51:390-391

44. Holland AE, Wilson JW, Kotsimbos TC, Naughton MT (2003) Metabolic alkalosis contributes to acute hypercapnic respiratory failure in adult cystic fibrosis. Chest 124:490-493

45. Holland AE, Wilson JW, Kotsimbos TC, Naughton MT (2004) Metabolic alkalosis and cystic fibrosis. Chest 125:1169-1170

46. Hooman N, Jafari D, Jalali-Farahani S, Lahouti Harahdashti A (2012) An infant with alternating metabolic acidosis and alkalosis. Pediatr Nephrol 27:51-54

47. Issa ARA, Teebi AS, Issa MA, Shaabani IS, Ramadan DJ (1988) Metabolic alkalosis in cystic fibrosis: atypical presentation in Kuwait. Ann Trop Paediatr 8:271-272

48. Kabra SK, Kabra M, Lodha R, Shastri S, Ghosh M, Pandey RM, Kapil A, Aggarwal G, Kapoor V (2003) Clinical profile and frequency of delta 508 mutation in Indian children with cystic fibrosis. Indian Pediatr 40:612-619

49. Kaskavage J, Sklansky D (2012) Hyponatremia-associated rhabdomyolysis following exercise in an adolescent with cystic fibrosis. Pediatrics 130:e220-e223

50. Kennedy JD, Dinwiddie R, Daman-Willems C, Dillon MJ, Matthew DJ (1990) Pseudo-Bartter's syndrome in cystic fibrosis. Arch Dis Child 65:786-787

51. Khorasani E (2011) Case of Pseudo-Bartter's Syndrome: an atypical presentation of cystic fibrosis. J Nepal Paediatr Soc 31: 121-123

52. Kleta R, Brune T, Harms E (1999) Cystic fibrosis and metabolic alkalosis in children - revisited. Miner Electrolyte Metab 25:210

53. Kose M, Pekcan S, Ozcelik U, Cobanoglu N, Yalcin E, Dogru D, Kiper N (2008) An epidemic of pseudo-Bartter syndrome in cystic fibrosis patients. Eur J Pediatr 167:115-116

54. Kriemler S, Wilk B, Schurer W, Wilson WM, Bar-Or O (1999) Preventing dehydration in children with cystic fibrosis who exercise in the heat. Med Sci Sports Exerc 31:774-779

55. Kurlandsky LE (2002) Failure to recognize the association of cystic fibrosis and metabolic alkalosis. Clin Pediatr (Phila) 41:715-719

56. Laughlin JL, Brady MS, Eigen H (1981) Changing feeding trends as a cause of electrolyte depletion in infants with cystic fibrosis. Pediatrics 68:203-207

57. Legris GJ, Dearborn D, Stern RC, Geiss CL, Hopfer U, Douglas JG, Doershuk CF (1998) Sodium space and intravascular volume: dietary sodium effects in cystic fibrosis and healthy adolescent subjects. Pediatrics 101:48-56

58. Leoni GB, Pitzalis S, Podda R, Zanda M, Silvetti M, Caocci L, Cao A, Rosatelli MC (1995) A specific cystic fibrosis mutation (T3381) associated with the phenotype of isolated hypotonic dehydration. $\mathrm{J}$ Pediatr 127:281-283

59. Lumpaopong A, Thirakhupt P, Srisuwan K, Chulamokha Y (2009) Rare F311L CFTR gene mutation in a child presented with recurrent electrolyte abnormalities and metabolic alkalosis: case report. J Med Assoc Thail 92:694-698

60. Marah MA (2010) Pseudo-Bartter as an initial presentation of cystic fibrosis. A case report and review of the literature. East Mediterr Health J 16:699-701

61. Mathew PM, Hamdan JA, Nazer H (1991) Cystic fibrosis presenting with recurrent vomiting and metabolic alkalosis. Eur J Pediatr 150:264-266

62. Mauri S, Pedroli G, Rüdeberg A, Laux-End R, Monotti R, Bianchetti MG (1997) Acute metabolic alkalosis in cystic fibrosis: prospective study and review of the literature. Miner Electrolyte Metab 23:33-37 
63. Muñoz AI, Rodríguez A, Jiménez JF (1983) Cystic fibrosis of the pancreas presenting as metabolic alkalosis. Bol Asoc Med P R 75: 230-231

64. Nahida e-R, Mohammed H, Guy L (2011) Pseudo-Bartter's syndrome revealing cystic fibrosis in an infant caused by $3849+1 \mathrm{G}>\mathrm{A}$ and 4382delA compound heterozygosity. Acta Paediatr 100:e234 e235

65. Nussbaum E, Boat TF, Wood RE, Doershuk CF (1979) Cystic fibrosis with acute hypoelectrolytemia and metabolic alkalosis in infancy. Am J Dis Child 133:965-966

66. Omron EM (2004) Metabolic alkalosis and cystic fibrosis. Chest 125:1169

67. Özçelik U, Göçmen A, Kiper N, Coșkun T, Yilmaz E, Özgüç M (1994) Sodium chloride deficiency in cystic fibrosis patients. Eur J Pediatr 153:829-831

68. Öztürk Y, Soylu OB, Arslan N (2006) Prevalence and clinical features of cystic fibrosis with pseudo-Bartter syndrome. Ann Trop Paediatr 26:155

69. Pavone MA, Solís Padrones A, Muratore DG, Saiz M, Puig C (2010) Hyponatraemia, hypopotassaemia and pre-renal acute renal failure as a presentation of cystic fibrosis. Nefrologia 30: 481-482

70. Pedroli G, Liechti-Gallati S, Mauri S, Birrer P, Kraemer R, FolettiJäggi C, Bianchetti MG (1995) Chronic metabolic alkalosis: not uncommon in young children with severe cystic fibrosis. Am J Nephrol 15:245-250

71. Priou-Guesdon M, Malinge MC, Augusto JF, Rodien P, Subra JF, Bonneau D, Rohmer V (2010) Hypochloremia and hyponatremia as the initial presentation of cystic fibrosis in three adults. Ann Endocrinol (Paris) 71:46-50

72. Rapaport R, Levine LS, Petrovic M, Wilson T, Draznin M, Bejar RL, Johanson A, New MI (1981) The renin-aldosterone system in cystic fibrosis. J Pediatr 98:768-771

73. Rendle-Short J (1956) Fibrocystic disease of the pancreas presenting with acute salt depletion. Arch Dis Child 31:28-30

74. Rodríguez Portales JA, Delea CS (1986) Renal tubular reabsorption of chloride in Bartter's syndrome and other conditions with hypokalemia. Clin Nephrol 26:269-272

75. Ruddy R, Anolik R, Scanlin TF (1981) Hypoelectrolytemia as a presentation and complication of cystic fibrosis. Clin Pediatr (Phila) 21:367-369

76. Salvatore D, Tomaiuolo R, Abate R, Vanacore B, Manieri S, Mirauda MP, Scavone A, Schiavo MV, Castaldo G, Salvatore F (2004) Cystic fibrosis presenting as metabolic alkalosis in a boy with the rare D579G mutation. J Cyst Fibros 3:135-136

77. Schiffer M, Lynch R (1977) Inappropriate secretion of ADH as a cause of hyponatremia in cystic fibrosis. J Pediatr 91:850-851

78. Sheth KJ, Heimler R (1977) Cystic fibrosis in an infant presenting with metabolic alkalosis. Wis Med J 76[Suppl]:47-49

79. Smith HR, Dhatt GS, Melia WM, Dickinson JG (1995) Cystic fibrosis presenting as hyponatraemic heat exhaustion. BMJ 310: 579-580

80. Sovtić A, Minić P, Bogdanović R, Stajić N, Rodić M, MarkovićSovtić G (2012) Atypical presentation of cystic fibrosis - obese adolescent with hypertension and pseudo-Bartter's syndrome. Vojnosanit Pregl 69:367-369

81. Stenvinkel P, Hjelte L, Alván G, Hedman A, Hultman E, Strandvik B (1991) Decreased renal clearance of sodium in cystic fibrosis. Acta Paediatr Scand 80:194-198

82. Sweetser LJ, Douglas JA, Riha RL, Bell SC (2005) Clinical presentation of metabolic alkalosis in an adult patient with cystic fibrosis. Respirology 10:254-256

83. Teeratakulpisarn J, Kosuwon P, Srinakarin J, Panthongviriyakul C, Sutra S (2006) Cystic fibrosis in three northeast Thai infants is CF really a rare disease in the Thai population? J Med Assoc Thail 89: $1756-1761$
84. Trauer JM, Wrobel JP, Young AC (2008) The syndrome of inappropriate anti-diuretic hormone secretion concurrent with an acute exacerbation of cystic fibrosis. J Cyst Fibros 7:573575

85. vande Velde S, Verloo P, Van Biervliet S, Robberecht E (2007) Heroin withdrawal leads to metabolic alkalosis in an infant with cystic fibrosis. Eur J Pediatr 166:75-76

86. Vertolli U, Ruffatti AM, De Giorgi ML, Scapin V, Naso A, Calò LA (2013) A very unusual case of hypokalaemia. Clin Kidney J 6:8789

87. Wahab AA, Janahi IA, Marafia MM (2004) Pseudo-Bartter's syndrome in an Egyptian infant with cystic fibrosis mutation N1303K. J Trop Pediatr 50:242-244

88. Wang MC, Shu SG, Chang SM, Ho WL, Chi CS (1993) Cystic fibrosis in two Chinese infants in Taiwan. Acta Paediatr Sin 34:314 321

89. Williams AJ, McKiernan J, Harris F (1976) Heat prostration in children with cystic fibrosis. BMJ 273:297

90. Yalçin E, Kiper N, Doğru D, Ozçelik U, Aslan AT (2005) Clinical features and treatment approaches in cystic fibrosis with pseudoBartter syndrome. Ann Trop Paediatr 25:119-124

91. Yalçın SS, Akça T, Genç Ö, Çelik M, Doğru D, Özçelik U (2007) Modified oral rehydration therapy in a case with cystic fibrosis. Turk J Pediatr 49:102-104

92. Yiallouros PK, Neocleous V, Zeniou M, Adamidou T, Costi C, Christophi C, Tzetis M, Kanavakis E, Deltas C (2007) Cystic fibrosis mutational spectrum and genotypic/phenotypic features in Greek-Cypriots, with emphasis on dehydration as presenting symptom. Clin Genet 71:290-292

93. Živanović S, Šaranac L, Kostić G (2008) The case of PseudoBartter's syndrome: an atypical presentation of cystic fibrosis. Med Biol 15:33-36

94. Dahabreh MM, Najada AS (2013) Pseudo-Bartter syndrome, pattern and correlation with other cystic fibrosis features. Saudi J Kidney Dis Transpl 24:292-296

95. Aguirre I (2010) Fibrosis quística en el Perú. Neumol Pediatr 20:52

96. Aranzamendi RJ, Breitman F, Asciutto C, Delgado N, Castaños C (2008) Deshidratación con alcalosis hipoclorémica: presentación inusual de fibrosis quística en un lactante. Arch Argent Pediatr 106:443-446

97. Campaňá-Cobas NG, Razón Behar R, Álvarez SD, Mañalich Coma R, Valdés Mesa M, Hernández Hernández JS (2008) Fibrosis quística que simula un síndrome de Bartter. Rev Cubana Pediatr 80. Available at: www.scielo.sld.cu/scielo.php

98. Frontera Izquierdo P, Cabezuelo Huerta G (1980) Alcalosis metabólica en un lactante come primera manfestación clínica de mucoviscidosis. An Esp Pediatr 13:731-732

99. Param T, Aldunate D (1988) Alcalosis metabólica en fibrosis quística del páncreas. Rev Chil Pediatr 59:322-325

100. Saieh CA, Rodríguez JA, Paris EM, Fuentes AG, Letelier GG (1982) Alcalosis metabólica hipokalémica: importancia del cloro. Rev Chil Pediatr 53:233-236

101. Götz M, Parth K, Singer P, Weissenbacher G (1976) Hypochlorämische Alkalose und sekundärer Hyperaldosteronismus bei Mukoviszidose. Pädiatr Pädol 11:275-282

102. Sauter R, Will M, Helwig H (1997) Schwere Hyponatriämie als diagnoseweisendes Symptom der cystischen Fibrose. Klin Padiatr 209:361-363

103. Weller F, Wiebicke W, Tümmler B (2000) Türkischer Säugling mit Hypoelektrolytämie und metabolischer Alkalose als alleinige Manifestation einer milden Form einer zystischen Fibrose (Mutation D110H). Klin Padiatr 212:41-43

104. Bérard E, Maillotte AM, Albertini M, Delalandre E, Boutté P, Mariani R (1994) Mucoviscidose révélée par une déshydratation avec alcalose hypochloronatrémique chez trois nourrissons et un nouveau-né. Arch Pediatr 1:42-45 
105. Desmazes-Dufeu N, Hubert D, Burgel PR, Kanaan R, Vélea V, Dusser D (2005) Déshydratation sévère, consequence de la canicule d'août 2003 sur une cohorte d'adultes atteints de mucoviscidose. Presse Med 34:647-648

106. Sanfelice NFT, Zucchi L (1998) Síndrome de Bartter: relato de dois casos em crianças. J Pediatr (Rio J) 74:473-478

107. Santos GPC, Cecon MR, Riedi CA, Dias LM, Braga MC, Rosário NA (2007) Alcalose hipoclorêmica em pacientes com fibrose cística-relato de 6 casos. J Paran Pediatr 8: $43-44$
108. Luke RG, Galla JH (2012) It is chloride depletion alkalosis, not contraction alkalosis. J Am Soc Nephrol 23:204-207

109. Peruzzo M, Milani GP, Garzoni L, Longoni L, Simonetti GD, Bettinelli A, Fossali EF, Bianchetti MG (2010) Body fluids and salt metabolism - part II. Ital J Pediatr 36:78

110. Royer P (1975) Métabolisme du sodium et développement prénatal et postnatal. Arch Fr Pediatr 32:497-502

111. Miozzari HH, Tönz M, von Vigier RO, Bianchetti MG (2001) Fluid resuscitation in infantile hypertrophic pyloric stenosis. Acta Paediatr 90:511-514 